Canadian Music: The Bibliographical Record

Canadian music, a selected checklist 19501973, Lynne Jarman, editor. Toronto: University of Toronto Press, 1976. xiv, 170 (240 biling.) p., cloth, $\$ 10.00$ ISBN 0-80205327-0

Canadian Music Scores and Recordings, a Classified Catalogue of the Holdings of Mount Allison University Libraries, compiled by Gwendolyn Creelman, Esther Cooke and Geraldine King. Sackville, New Brunswick: Ralph Packard Bell Library, Mount Allison University, 1976. vii, 192 p., paper, price not ascertained ISBN 0-88828-000-9

Canadian composers have had little more than a century to create a substantial body of Canadian music. In fact, there were relatively few scores available prior to World War II, and scarcely any recordings before 1967. Increased publishing and recording activity during this past decade has not gone unnoticed, as evidenced by the recent appearance of no less than three musical bibliographies.

In his foreword to the Jarman catalogue, Helmut Kallmann aptly describes the book as ". . .tailor-made for librarians ... [It provides] a painless means of building and cataloguing a collection of Canadian music." The book lists approximately 470 books and scores, all arranged according to the Dewey Decimal Classification, 18 th edition. Criteria for selection and the qualifications of the selectors are beyond dispute. Jarman, former music subject analyst at the National Library, based her selection on listings in Fontes Artis Musicae, the journal of the International Association of Music Libraries, and Canadiana. Included is music of "serious intent" and of a "certain length or substance." It is unfortunate that some top-rate compositions not commercially published, and only available through the Canadian Music Centre, had to be excluded.

The Mount Allison bibliography lists over 2600 printed scores, scores on microfilm, and recordings, all arranged according to the Library of Congress M Schedule. The catalogue's raison d'être is simply to show how much Canadian music one Maritime university has acquired. This sizeable book could have been a valuable source of information had the cataloguing copy been edited, the typing errors corrected, index page references double-checked, table of contents extended, basic arrangement of entries revised, and a composer/title index added. The descriptive cataloguing and uniform titles reveal a basic lack of knowledge of the Anglo-American Cataloging Rules. Religious folk will be amused by the "Huron Press scared series." Entries \#1977 and \#1978 are not works by Jones and MacMillan respectively. Because the overall arrangement of entries is extremely poor, access is difficult. For example, groups of recordings follow groups of scores. To further complicate retrieval, the index does not distinguish a composer's recordings from his scores let alone the titles of his works. The compilers should have either interfiled scores with recordings, or had two completely separate sections. Two different qualities of paper were used in the copy reviewed and the typewritten reproduction was not always clear. On the positive side, however, one will find some rather obscure composers listed (as well as most of the major ones recommended by Jarman). Record and score analytics could also prove useful for other libraries.

While the Jarman book is easier to read and seems a better purchase all around, it too has its limitations. Prices for listed items in many instances bear no resemblance to present-day values and could have been entirely omitted. Those users unfamiliar with DDC would have found a detailed table of contents or a subject index helpful. But these are minor complaints in light of the obvious usefulness of this attractive bibliography, complete with a selected list of Canadian publishers. Unfortunately, inadequacies in the Mount Allison catalogue are too numerous to be overlooked.

Rhoda Resnick

(Ms. Resnick is a librarian at the Metropolitan Toronto Library, Music Department, a reviewer for the Canadian Book Review Annual, and a contributor to the Encyclopedia of Music in Canada.)

\section{Canadian Theatre}

Canada On Stage. Canadian Theatre Review Yearbook 1976. [Don Rubin, Gen. Ed. Downsview: CTR Publications, 1977]. 442 p., \$14.95 ISSN 0380-9455

Stage Scenery, Machinery, and Lighting. A guide to information sources [by] Richard Stoddard. Detroit: Gale Research Co., 1977. (Performing Arts Information Guide Series, vol. 2) 274 p., $\$ 18.00$ ISBN 0-8103-1374-X 